\section{ANALYSIS OF EVAPORATOR EFFECTIVENESS ON 1/2 CYCLE REFRIGERATION SYSTEMS: A CASE STUDY ON LPG FUELED VEHICLES}

\author{
Muji Setiyoa,b*, Budi Waluyoa,b, Nurkholis Hamidic
}

aDepartment of Automotive Engineering, Universitas Muhammadiyah Magelang, Magelang, Indonesia bCenter for Energy Studies, Universitas Muhammadiyah Magelang, Magelang, Indonesia

cDepartment of Mechanical Engineering, Universitas Brawijaya, Malang, Indonesia
Article history

Received

5 December 2018

Received in revised form

12 December 2019

Accepted

4 March 2020

Published online

23 April 2020

*Corresponding author setiyo.muji@ummgl.ac.id

\section{Graphical abstract}

THE CONCEPT OF $1 / 2$ CYCLE REFRIGERATION SYSTEM

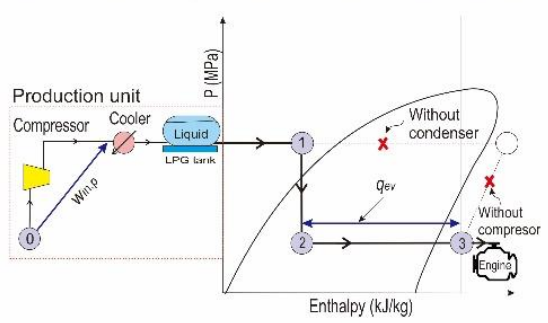

\begin{abstract}
The $1 / 2$ cycle refrigeration system on LPG fueled vehicles has a significant cooling effect. However, the cooling is very dependent on the heat exchange process in the evaporator. Therefore, this paper analyses the deviation of the actual cooling curve from the ideal scenario carried out on a laboratory scale. The analytical method used is the calculation of the effectiveness of the evaporator, which compares the actual to the potential heat transfer capacity. The LPG flow rate was varied from 1-6 $\mathrm{g} / \mathrm{s}$, while the evaporation pressure ranged between $0.05,0.10$, and $0.15 \mathrm{MPa}$, which applied to compact type evaporators with dimensions of $262 \times 200 \mathrm{~mm}$, with a thickness of $65 \mathrm{~mm}$. The research results confirm that the higher the LPG mass flow rate, the lower the heat transfer effectiveness. At the higher LPG mass flow rate, heat transfer occurs less optimally, due to incomplete evaporation of LPG in the evaporator.
\end{abstract}

Keywords: LPG fueled vehicle, 1/2 cycle refrigeration, COP, evaporator effectiveness

\subsection{INTRODUCTION}

The Air Conditioning (AC) system has, for long, been used as a supporting mechanism for a passenger car. Before 1940, adjusting the vent or opening the side glasses was the only way one could be comfortable in a car [1]. However, Packard became the first car manufacturer that complements its products with an AC system in 1940. The cooling system equipment is located in the rear trunk, unlike the current $A C$ mechanism, which is compactly designed in the engine chamber and inside the dashboard. Then, more than half of the new cars were equipped with AC systems that could be operated easily in 1969 [2].

For many years, the AC system of passenger cars utilized a vapor compression refrigeration mechanism. The working principle of the main components is less developed, except for compressors and refrigerants due to the demands of efficiency and the environment effect [3-4]. The main components and refrigerant cycle of the vapor-compression AC system are shown in Figure 1, where $1 \rightarrow 2$ represents the isentropic compression process, $2 \rightarrow 3$ condensation process at constant pressure, $3 \rightarrow 4$ isenthalpic expansion process, and $4 \rightarrow 1$ represent evaporation process or harvesting cooling effect.

Along with development of technology, at present, the vehicle's AC system has been able to regulate automatically based on internal temperatures, but have considered the effects of solar radiation, vehicle speed, and external temperatures [6]. The mechanism of controlling the compressor on the AC system has also been developed, from manual, electric, to virtual controlling [7-8]. 


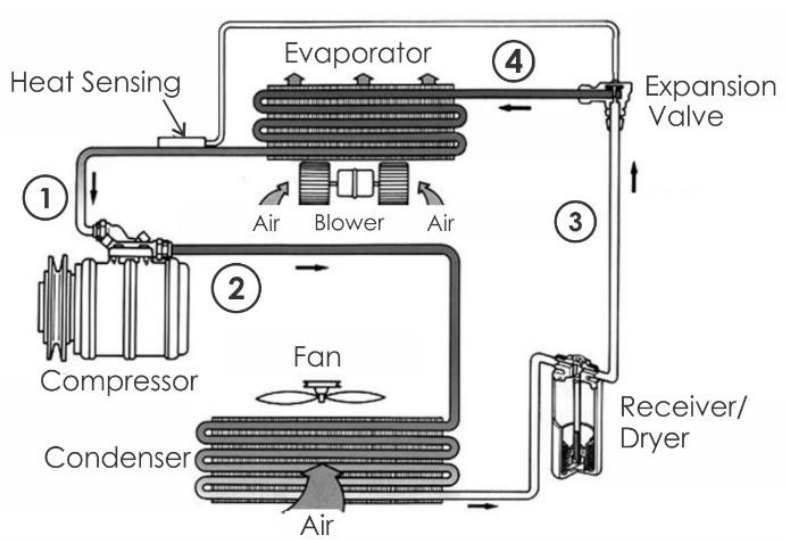

Figure 1 Basic component and refrigerant cycle of vaporcompression AC system applied to passenger cars [5]

\subsection{Some Alternative Technologies to Replace Conventional AC System}

Generally, the car AC system works based on the vapor compression cycle. However, due to the demands of engine efficiency and environmental issues, and absorption system has been developed for several years, for exemple, the one examined by Chandrakar [9]. Thermal energy from the exhaust gas is used in the absorption refrigeration systems. From theoretical designs, it is verified in the laboratory and road tests. This system has been utilized for long, though it only produces COP ranging from 0.8 to 0.9 . It was also researched and applied to the truck cabin, where the developed absorption system produces a cooling capacity of up to $1.2 \mathrm{~kW}$, with a COP $\leq 0.45$ [10].

Another absorption system is developed by heat supply from the loop of the engine coolant [11]. A test was carried out by installing the adsorption chiller into a prototype of the truck cabin, producing an air temperature of $9^{\circ} \mathrm{C}$ with a cooling capacity estimated at $2 \mathrm{~kW}$. For long, the absorption system has been perceived as a better choice for replacing the vapor compression mechanism, even though its performance is still relatively low [12-15].

In terms of material optimization, a simulation of the absorption refrigeration system with energy from the exhaust gas is developed, especially for evaporator and condenser [16]. All parts needed for absorption refrigeration systems are designed and modeled in the Pro/Engineer software and analyzed by ANSYS. The results of the simulation show that the evaporator and condenser made of aluminum alloy have a better performance than copper.

Apart from the absorption system, a compressor with external power is also developed. A biogas engine with constant rotation is used to drive an $A C$ compressor [17]. With this system, it produces 1 Ton of Refrigeration (TR), which is equivalent to the cooling load of passenger cars. This study refers to Damrongsak [18], who removed the AC system from the car to be tested with small-sized biogas or compact modular engine. It produces a cooling effect of $3.5 \mathrm{~kW}$ on the compressor rotation of 1000 rpm. However, the AC system with an external mechanical drivehas only been studied on a laboratory scale. Application to vehicles is more complicated since it requires two engines and fuel systems.

A turbo system develops a new method of driving an AC compressor to reduce engine load. Primarily, kinetic energy and exhaust gas pressure are used to rotate the turbo and the $\mathrm{AC}$ compressor with a magnetic gear connector [19]. One of the main advantages of this concept is that it can be easily applied for low-capacity engines. It offers better utilization of exhaust gas energy and reduces fuel consumption. Although this study is still in the proposed model, it might be applied on a special scale by the rapid advancement of technology in the thermomechanical field.

Although absorption refrigeration and other systems cannot yet replace the vapor compression mechanism, it is necessary to develop an alternative option for passenger vehicles that low in energy input. This because a compressed vapor AC system requires much energy serves as an engine load. The fuel consumption due to the $A C$ system is diverse depending on technology and heat load, though almost all researchers agree that it is significant and must be reduced [20-24].

\subsection{Experiences from Previous Research: Performance of $1 / 2$ Cycle AC Systems in LPG Vehicles}

In previous research, laboratory-scale tests on $1 / 2$ cycle AC systems applied to LPG fueled vehicles were examined. The phase change of LPG from liquid to vapor on the fuel line requires evaporation heat. The fuel system was modified to replace the loop engine coolant in the evaporator with air. LPG absorbs heat from the air that crosses the evaporator and resulting in cold air moves to the cabin to produce a cooling effect. Numerical studies are conducted with data obtained from LPG properties as well as specific state points in preliminary research [25-26]. As a result, the $1 / 2$ cycle system provides a promising cooling effect. In general, the cooling effect of more than $1.2 \mathrm{~kW}$ at a mass flow rate of LPG $3 \mathrm{~g} / \mathrm{s}$ or higher can be harvested without using the compressor [27]. The highest COP value of this study was 6.27, which was obtained at an LPG mass flow rate of $1 \mathrm{~g} / \mathrm{s}$ and evaporation pressure of $0.15 \mathrm{MPa}$.

However, the cooling effect produced is not linear, with an increase in LPG mass flow rate. Previous studies have not addressed this weakness. Moreover, previous works attribute this problem to LPG evaporation at a mass flow rate above $3 \mathrm{~g} / \mathrm{s}$, which is imperfect, as shown in Figure 2. Some LPG leaves evaporator in the form of a mixture of vapor and liquid. Also, heat exchange occurs optimally in case LPG exits the evaporator in the form of saturated or superheated vapor. Therefore, this paper analyzes heat transfer in LPG evaporators in terms of effectiveness $(\epsilon)$. 


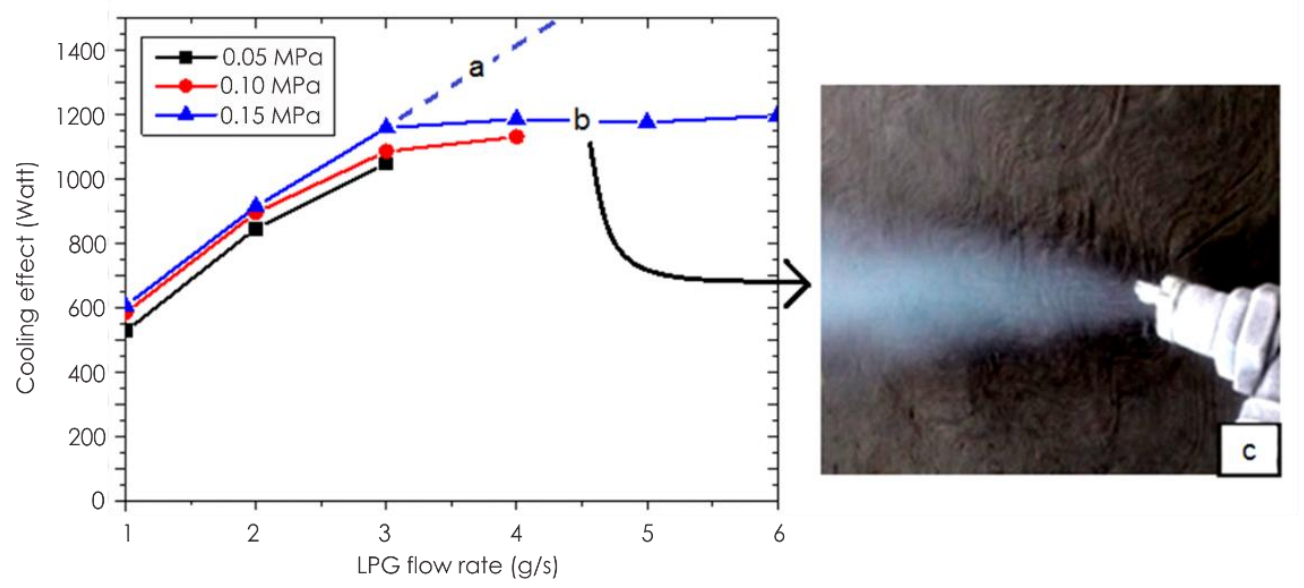

Figure 2 Problems in previous research: (a) ideal cooling effect curve, (b) cooling effect curve of test results (actual), and (c) incomplete evaporation of LPG that comes out of the evaporator [27]

\subsection{METHODOLOGY}

\subsection{Experiment Set up and Limitation}

The $1 / 2$ cycle refrigeration system involves working of the compressor and condenser like a full cycle system. The cooling effect is obtained only by dropping LPG pressure on the expansion valve and harvesting the cooling effect on the evaporator. Pressurized LPG is supplied from the tank. The concept and specific state points of the $1 / 2$ cycle refrigeration system are presented in Figure 3, where $1 \rightarrow 2$ represents the isenthalpic expansion, while $2 \rightarrow 3$ is the evaporation. There is no process from 3 to 1 since the LPG from point 3 is fed to the engine as fuel. $0 \rightarrow 1$ represents a process outside the fuel system in the vehicle, which describes how LPG is produced into pressurized commercial products in the tank.
In this study, LPG is maintained in the form of liquid in the tank by monitoring the pressure and temperature. Its mass flow rate at point 1 is varied at $1-6 \mathrm{~g} / \mathrm{s}$, which represents the fuel consumption of passenger vehicles [28]. Besides, evaporation pressure at 2-3 is set at 0.05, 0.10 , and $0.15 \mathrm{MPa}$ for each mass flow rate. Setting the mass flow rate and pressure is conducted on a specially designed expansion valve made of Teflon, which has a low thermal conductivity for more benefits. During testing, pressure and temperature in each specific state point were observed with RTD thermocouple and PSAN pressure transducer connected to the computer through the module. DAQ Master software supported by Autonics conducts the monitor screen reading.

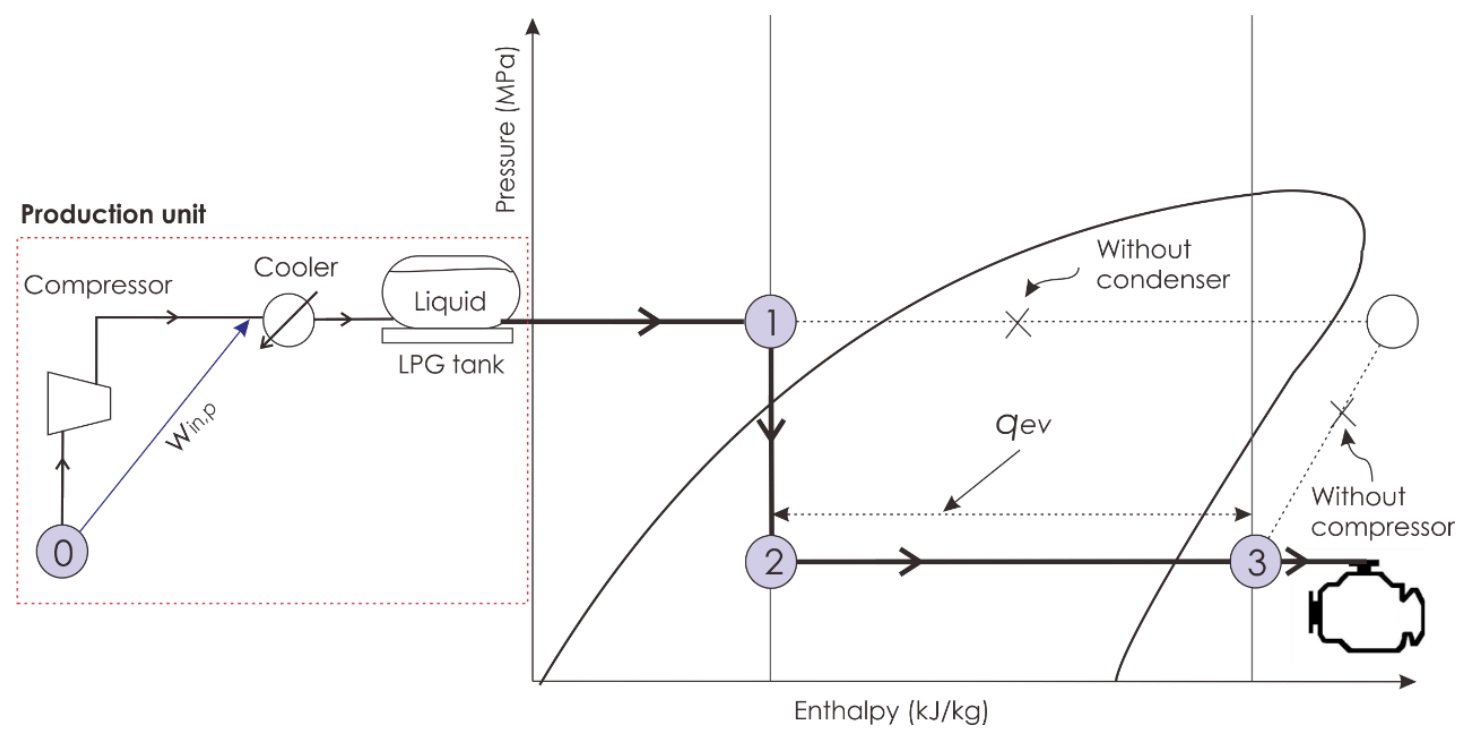

Figure 3 Concept and specific state points of the $1 / 2$ cycle refrigeration system [27] 


\subsection{Analysis Method}

In this study, LPG in the tank is in the form of pressurized liquid. For this reason, work in the system is calculated as the work of compressors to increase pressure in the production process before LPG is supplied to dispensers at a gas station. Assuming there is no heat entering and exiting the system during compression which takes place in an isentropic manner, there is no change in entropy. Figure 4 shows the boundary system and $T$-s diagram for calculating the work input.

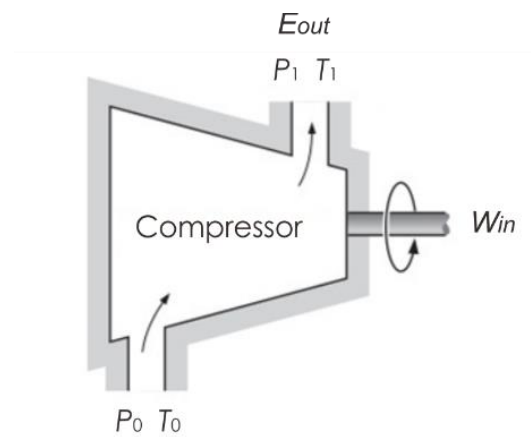

(a)

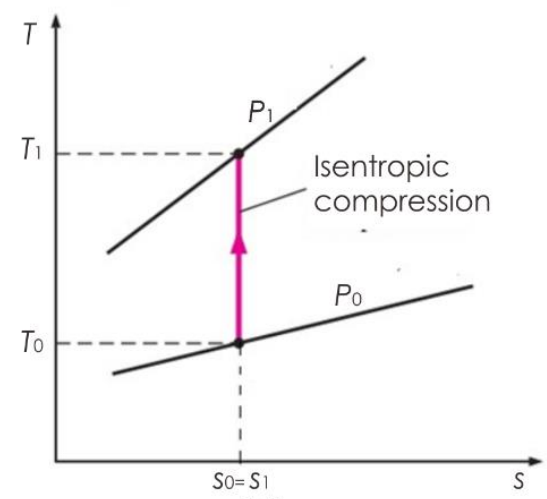

(b)

Figure 4 Isentropic compression process: (a) Boundary system and (b) T-s diagram

From Figure 3 and Figure 4, relationship between temperature, enthalpy and pressure on compressor work is given in the Equation (1) to Equation (4) as follows [30].

$$
E_{\text {in }}=E_{\text {out }}
$$

Assuming that kinetic energy and potential energy are ignored because change in speed is very small and there is no change in altitude, then:

$$
\begin{gathered}
w_{\text {in }}+h_{0}\left(P_{0}, T_{0}\right)=h_{1}\left(P_{1}, T_{1}\right) \\
w_{\text {in }}=h_{1}\left(P_{1}, T_{1}\right)-h_{0}\left(P_{0}, T_{0}\right)
\end{gathered}
$$

Assuming that compression is isentropic ( $d s=0$ ) then $T d s=0$. Thus, the work of compressors to produce pressurized liquid LPG is stated below.

$$
w_{\text {in,p }}=\int_{0}^{1} d h=h_{1}-h_{0}
$$

Apart from the COP (general method for measuring the performance of an AC system), which was generally utilized to analyze cooling performance $(2 \rightarrow 3)$, this study uses the calculation of the effectiveness of heat exchange in the evaporator. The formula for heat transfer effectiveness is given in Equation (5) [29].

$$
\in=\frac{T_{1, o}-T_{1, i}}{T_{2, i}-T_{1, i}}
$$

In this case, $T_{1, i}$ and $T_{1,0}$ are temperatures of LPG entering and leaving the evaporator, respectively. Also, $T_{2, i}$, and $T_{2,0}$ are the temperature of the air entering and exiting across the evaporator, as presented in Figure 5.

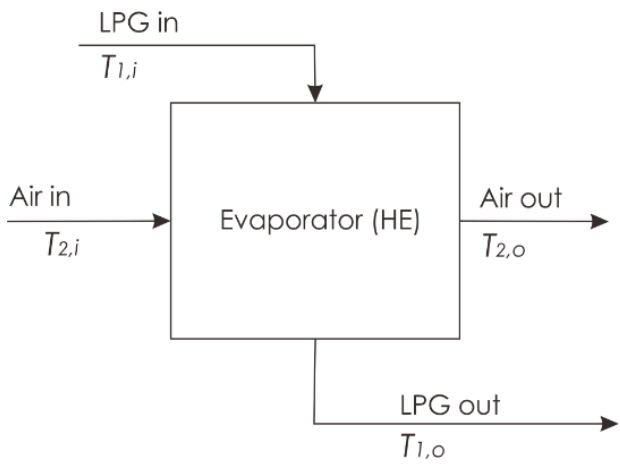

Figure 5 Sketch of heat transfer in the evaporator

\subsection{RESULTS AND DISCUSSION}

\subsection{Cooling Effect and COP}

This test results showed that the $1 / 2$ cycle refrigeration system produces a cooling effect of up to $1.2 \mathrm{~kW}$, with data shown in Table 1.

Table 1 Cooling effect $\left(\dot{Q}_{e v}\right)$ at variations of LPG mass flow rate and evaporation pressure

\begin{tabular}{cccc}
\hline $\begin{array}{c}\text { LPG flow rate } \\
\text { (g/s) }\end{array}$ & \multicolumn{3}{c}{$\dot{\mathbf{Q}}_{\mathbf{e v}}$ (Watt) at evaporation pressure of } \\
& $\mathbf{0 , 0 5} \mathbf{~ M P a}$ & $\mathbf{0 , 1 0} \mathbf{~ M P a}$ & $\mathbf{0 . 1 5} \mathbf{~ M P a}$ \\
\hline 1 & 527 & 584 & 606 \\
2 & 846 & 896 & 925 \\
3 & 1048 & 1087 & 1125 \\
4 & $\mathrm{n} / \mathrm{a}$ & 1132 & 1186 \\
5 & $\mathrm{n} / \mathrm{a}$ & $\mathrm{n} / \mathrm{a}$ & 1177 \\
6 & $\mathrm{n} / \mathrm{a}$ & $\mathrm{n} / \mathrm{a}$ & 1198 \\
\hline
\end{tabular}


Furthermore, the input work ( $W$ in) is calculated based on the compressing LPG from $24^{\circ} \mathrm{C}$ and $0 \mathrm{MPa}$ to 0.7 $\mathrm{MPa}$. In this case, the input produces pressurized liquid LPG (Win,p). Assuming that the process of compression is isentropic, using NIST REFPROP, data on density, enthalpy, and entropy are obtained, as shown in Figure 6. Data on the first and second lines represent the condition of LPG entering and exiting the compressor, respectively.

\begin{tabular}{|c|c|c|c|c|c|}
\hline File Edit $O p$ & ions Substance & Calculate Plot Window H & Caution: & & \\
\hline \multicolumn{6}{|c|}{ 10: propane/isopentane: Specified state points [Barometric pressure: 0,10133 M... } \\
\hline & $\begin{array}{c}\text { Temperature } \\
\text { ("C) }\end{array}$ & $\begin{array}{l}\text { Pressure } \\
\text { (MPa_g) }\end{array}$ & $\begin{array}{l}\text { Density } \\
\left(\mathrm{kg} / \mathrm{m}^{3}\right)\end{array}$ & $\begin{array}{c}\text { Enthalpy } \\
(\mathrm{kJ} / \mathrm{kg})\end{array}$ & $\begin{array}{c}\text { Entropy } \\
(\mathrm{kJ} / \mathrm{kg}-\mathrm{K})\end{array}$ \\
\hline 1 & 24,000 & 0,0000000000000000065526 & 2,3127 & 480.42 & 2.0642 \\
\hline 2 & 86,818 & 0,70000 & 16.606 & 576,80 & 2,0642 \\
\hline 3 & & & & & \\
\hline
\end{tabular}

Figure 6 LPG property when entering and exiting the compressor (in production unit)

Unlike the full cycle refrigeration system, where compressor works is not constant, in this study the work of the compressor is constant for all evaporated LPG mass flow rates. By Equation (5) and data from Figure 5, enthalpy LPG value when entering the compressor is $480.2 \mathrm{KJ} / \mathrm{kg}$ and enthalpy LPG out of compressor is $576.80 \mathrm{KJ} / \mathrm{kg}$. Thus, the compressor's work is:

$$
\begin{aligned}
& w_{i n, p}=\int_{0}^{1} d h \\
& w_{i n, p}=576,80-480,2 \quad[\mathrm{~kJ} / \mathrm{kg}] \\
& w_{\text {in,p }}=96,6 \mathrm{KJ} / \mathrm{kg}
\end{aligned}
$$

Then, by comparing the cooling effect $\left(\dot{Q}_{e v}\right)$ generated by work input of compressor $\left(\dot{W}_{i n, p}\right)$, the Coefficient of Performance (COP) is shown in Figure 7 as follows.

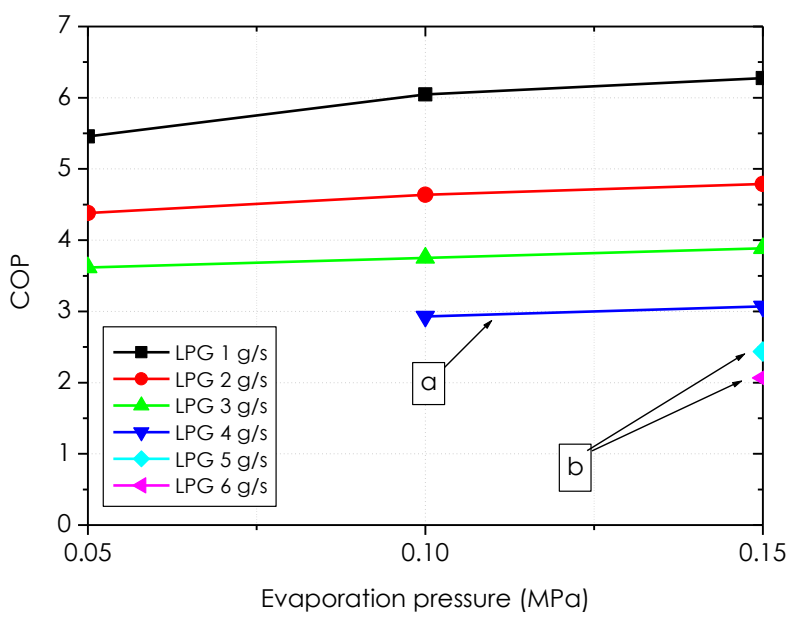

Figure $7 \mathrm{COP}$ at variations of LPG mass flow rate and evaporation pressure: (a) LPG $4 \mathrm{~g} / \mathrm{s}$ can only be flowed by evaporation pressures of 0.10 and $0.15 \mathrm{MPa}$, and (b) LPG 5-6 $\mathrm{g} / \mathrm{s}$ can only be flowed by evaporation pressures of $0.15 \mathrm{MPa}$
From Figure 7, two interesting phenomena need to be discussed. First, increasing evaporation pressure affect COP. At a pressure of $0.15 \mathrm{MPa}$, there is a transfer of latent heat as long as LPG in the evaporator is longer than sensible heat transfer. However, the difference in COP due to variations in evaporation pressure is smaller in case the mass flow rate is enlarged, as shown in Figure 8. Second, the higher the LPG mass flow rate, the smaller the COP produced. This is attributed to the increase in the cooling effect produced $\left(\dot{Q}_{e v}\right)$ not being linear with the increasing mass flow rate. Generally, increasing LPG mass flow rate also results in incomplete evaporation, as presented visually in Figure 2 [27]. Although the increase in mass flow rate increases the cooling effect $\left(\dot{Q}_{e v}\right)$, it may cause a decreasing in LPG temperature when exiting the evaporator. Since enthalpy values depend on temperature, the COP tends to decrease when the LPG mass flow rate increases.

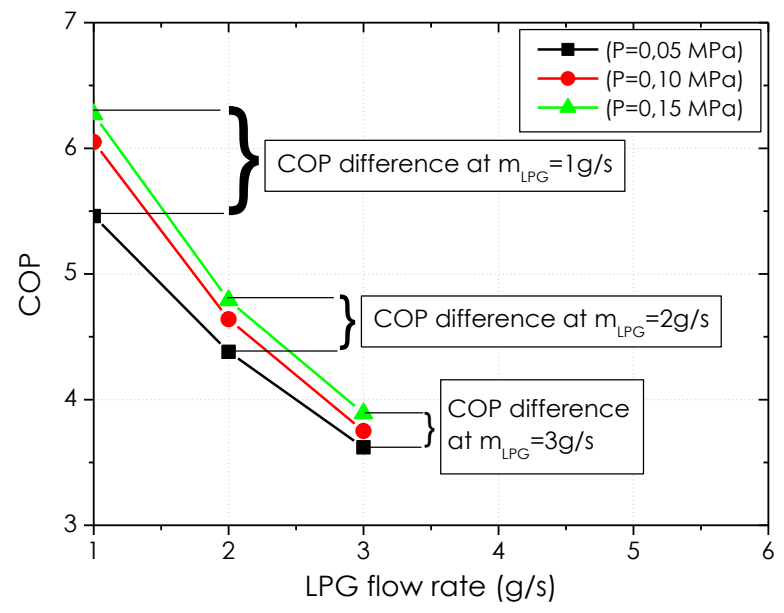

Figure 8 Effect of mass flow rate and evaporation pressure on the COP

\subsection{Evaporator Effectiveness}

The evaporator in LPG fuel systems is additional equipment attached to the fuel line, which serves to vaporize LPG. The heat to vaporize LPG is obtained from the air crossing fins, which are driven by electric blowers. Evaporator has dimensions of $262 \times 200 \mathrm{~mm}$, with a thickness of $65 \mathrm{~mm}$. From $T_{1, o}-T_{1, i}$ as the difference in actual temperature and $T_{2, i}-T_{1, i}$ the difference in maximum temperature (potential), and using Eq. (1), the effectiveness of evaporator on various evaporation pressures and mass flow rates is presented in Figure 9. 


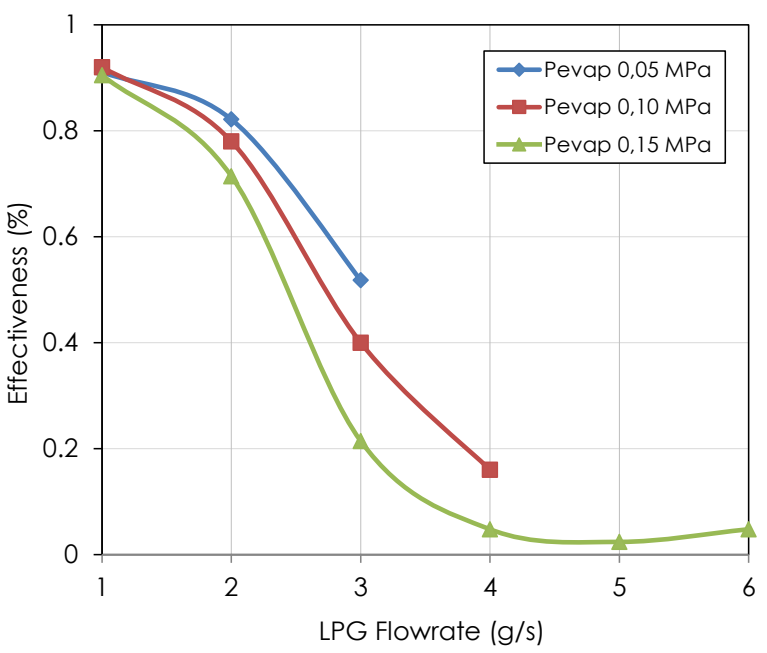

Figure 9 Effectiveness of heat transfer on the evaporator on variations LPG mass flow rate and evaporation pressure

Figure 9 shows the greater the LPG mass flow rate, the lower the heat transfer effectiveness. At a higher mass flow rate, heat transfer occurs less optimally, where the temperature on the evaporator exit side is lower. Finally, the COP curve and the cooling effect curve for mass flow rates are presented in Figure 10.

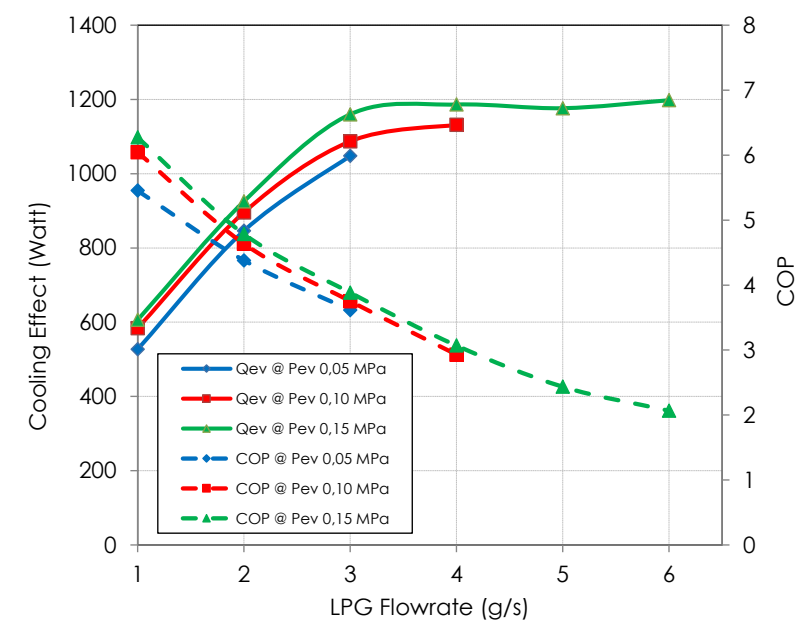

Figure 10 COP curve and cooling effect curve for LPG mass flow rate

\subsection{CONCLUSION}

From the analysis, the deviation of the actual cooling curve from an ideal cooling arc is due to the effectiveness of heat transfer in the evaporator. At a small LPG flow rate $(<3 \mathrm{~g} / \mathrm{s})$, transfers heat from the air to LPG for evaporation to be perfect, coming out as vapor or superheated vapor. However, in case the mass flow rate is enlarged, the evaporator cannot transfer heat properly due to the limitations of an effective area. At the flow rate greater than $3 \mathrm{~g} / \mathrm{s}$, LPG comes out of evaporator as a mixture of vapor and liquid. From the results of this analysis, various types of evaporators with greater heat transfer capacity still needs to be worked on.

\section{Acknowledgement}

This research is fully supported ass part of the development of an efficient vehicle project in the Automotive Laboratory of Universitas Muhammadiyah Magelang. The authors express their gratitude to the Laboratory staff who helped during apparatus preparation and data collection. This article was written in Dresden - Germany, in NovemberDecember 2018, when the first author joined the Short Course Vocational Education Program at TU Dresden.

\section{References}

[1] Bhatti, M. S. 1999. Evolution of Automotive Air Conditioning Riding in Comfort: Part II. ASHRAE Journal. 41(9): 44-50.

https://www.ashrae.org/.../docLib/.../2003627102420_326. pdf.

[2] Automobile. 2010. Automotive Air Conditioning-History, Automobile Megazine, (Accessed: 12 June 2016), http://www.automobilemag.com/news/automotive-airconditoning-history/.

[3] Zima, M. et al. 2014. Improving the Fuel Efficiency of Mobile A/C Systems with Variable Displacement Compressors. SAE Technical Paper. 2014-1-7. 1-6. Doi: 10.4271/2014-01-0700.

[4] Yang, Z. and Wu, X. 2013. Retrofits and Options for the Alternatives to HCFC-22. Energy. 59 (2013): 1-21.

Doi: 10.1016/j.energy.2013.05.065.

[5] Daly, S. 2006. Automotive Air-conditioning and Climate Control Systems, Igarss 2014. Oxford: Elsevier Ltd. http://www.sciencedirect.com/science/book/9780750669 559.

[6] Xie, Y. et al. 2019. A Self-learning Intelligent Passenger Vehicle Comfort Cooling System Control Strategy. Applied Thermal Engineering. 114646.

Doi: 10.1016/j.applthermaleng.2019.114646.

[7] Aiman, A. et al. 2014. Efficient and "Green" Vehicle Air Conditioning System using Electric Compressor. Energy Procedia. 270-273. Doi: 10.1016/j.egypro.2014.11.1105.

[8] Guo, Y. et al. 2017. Development of a Virtual VariableSpeed Compressor Power Sensor for Variable Refrigerant, International Journal of Refrigeration. 74(2017): 71-83. Doi: 10.1016/j.jirefrig.2016.09.025.

[9] Chandrakar, D. and Saikhedkar, N. K. 2016. Design of Ammonia Water Vapour Absorption Air Conditioning System for a Car by Waste Heat Recovery from Engine Exhaust Gas. Advance Physics Letter.3(2): 24-29.

[10] Tiwari, H. and Parishwad, G. V. 2012. Adsorption Refrigeration System for Cabin Cooling of Trucks, International Journal of Emerging Technology and Advanced Engineering. 2(10): 337-342.

http://www.ijetae.com/files/Volume2lssue 10/IJETAE_1012 60.pdf.

[11] Vasta, S. et al. 2012. Development and Lab-test of a Mobile Adsorption Air-conditioner. International Journal of Refrigeration. 35(3): 701-708.

Doi: 10.1016/j.jirefrig.2011.03.013.

[12] Aleixo, A. et al. 2010. Using Engine Exhaust Gas as Energy Source for an Absorption Refrigeration System. Applied Energy. 87(4): 1141-1148.

Doi: 10.1016/j.apenergy.2009.07.018.

[13] Rêgo, A. T. et al. 2014. Automotive Exhaust Gas Flow 
Control for an Ammonia-water Absorption Refrigeration System, Applied Thermal Engineering. 64(1-2): 101-107. Doi: 10.1016/j.applthermaleng.2013.12.018.

[14] Arrieta, F. R. P. et al. 2016. Exergoeconomic Analysis of an Absorption Refrigeration and Natural Gas-fueled Diesel Power Generator Cogeneration System. Journal of Natural Gas Science and Engineering. 36: 155-164. Doi: 10.1016/j.jngse.2016.10.022.

[15] Aly, W. I. A. et al. 2017. Thermal Performance of a Diffusion Absorption Refrigeration System Driven by Waste Heat from Diesel Engine Exhaust Gases. Applied Thermal Engineering. Elsevier Ltd. 114: 621-630.

Doi: 10.1016/j.applthermaleng.2016.12.019.

[16] Sowjanya, L. 2015. Thermal Analysis of a Car Air Conditioning System Based on an Absorption Refrigeration Cycle Using Energy from Exhaust Gas of an Internal Combustion Engine. Advanced Engineering and Applied Sciences. 3(4): 47-53. Available at: http://www.urpjournals.com.

[17] Koli, S. R. and Yadav, S. D. 2013. Experimental Investigation of Air Conditioning System in Automobile Using a Constant Speed Biogas Engine. International Journal of Automobile Engineering Research and Development. 3(1): 15-20.

http://www.tjprc.org/view-archives. php?year=2013\&id= 23\& jtype $=2 \&$ page $=1$.

[18] Damrongsak, D. and Tippayawong, N. 2010. Experimental Investigation of an Automotive Air-conditioning System Driven by a Small Biogas Engine. Applied Thermal Engineering. $\quad 30(5)$ : 400-405. Doi: 10.1016/j.applthermaleng.2009.09.003.

[19] Kumar, S. et al. 2014. Analysis on Turbo Air-Conditioner: An Innovative. International Journal of Mechanical And Production Engineering. 2(3): 38-41.

Doi: IJMPE-IRAJ-DOI-566.

[20] Li, C., Brewer, E., Pham, L., and Jung, H. 2018. Reducing Mobile Air Conditioner (MAC) Power Consumption Using Active Cabin-air-recirculation in a Plug-in Hybrid Electric Vehicle (PHEV). World Electric Vehicle Journal. 9(4): 1-15. Doi: 10.3390/wevj9040051.

[21] Weng, C. L., Kau, L. J. 2019. Design and Implementation of a Low-energy-consumption Air-conditioning Control System for Smart Vehicle, Journal of Healthcare Engineering. 1-14. Doi: 10.1155/2019/3858560.

[22] Zulkifli, A.A. et al. 2015. Impact of the Electric Compressor for Automotive Air Conditioning System on Fuel Consumption and Performance Analysis. IOP Conference Series: Materials Science and Engineering. 100(1). Doi: 10.1088/1757-899X/100/1/012028.

[23] Abas, M. A. et al. 2017. Fuel Consumption Evaluation of SI Engine Using Start-stop Technology. Journal of Mechanical Engineering and Sciences. 11(4): 2967-78. Doi: 10.15282/jmes.11.4.2017.1.0267.

[24] Shete, K. 2015. Influence of Automotive Air Conditioning load on Fuel Economy of IC Engine Vehicles. International Journal of Scientific \& Engineering Research. 6(8): 13671372.

[25] Setiyo, M. et al. 2017. Numerical Study on Cooling Effect Potential from Vaporizer Device of LPG vehicle. Journal of Engineering Science and Technology. 12(7): 1766-1779.

[26] Setiyo, M. et al. 2017. Cooling Effect Potential From Liquefied Petroleum Gas Flow in the Fuel Line of Vehicle. International Journal of Automotive and Mechanical EngineeringOnline. 14(4): 2229-8649. Doi: 10.15282/ijame.14.4.2017.9.0370.

[27] Setiyo, M., Soeparman, S., Hamidi, N. and Wahyudi, S. 2017. Cooling Effect Characteristics of a $1 / 2$ Cycle Refrigeration System on an LPG Fuel System. International Journal of Refrigeration. Elsevier Ltd. 82: 227-237. Doi: 10.1016/j.jirefrig.2017.06.009.

[28] Masi, M. and Gobbato, P. 2012. Measure of the Volumetric Efficiency and Evaporator Device Performance for a Liquefied Petroleum Gas Spark Ignition Engine. Energy Conversion and Management. Elsevier Ltd. 60: 18-27.

Doi: 10.1016/j.enconman.2011.11.030.

[29] Stoecker, W. F. 1989. Design of Thermal Systems. Singapore: McGraw-Hill.

[30] Çengel, Y. A. and Boles, M. A. 2007. Thermodynamics: An Engineering Approach. Sixth Edit. Singapore: McGraw-Hill. 